\title{
Pengaruh Pelatihan Kerja Terhadap Kinerja Karyawan Pada PT. Penerbit Erlangga Cabang Samarinda
}

\author{
Muhtar Sehe ${ }^{1}$, Syachrul $^{2 *}$, dan Zalfiani \\ ${ }^{123}$ Program Studi Administrasi Bisnis, Politeknik Negeri Samarinda, Samarinda 75131 \\ *Correspondent Author \\ E-mail: syachrulpolnes03@polnes.ac.id
}

Diterima: 25 Oktober 2020 Direvisi: 22 November 2020 Disetujui: 27 Desember 2020

\begin{abstract}
Abstrak
Kinerja karyawan adalah hasil yang dicapai dan prestasi yang ditunjukkan oleh karyawan yang membantu perusahaan untuk mewujudkan tujuan yang ditetapkannya. Salah satu cara yang dapat dilakukan untuk mencetak sumber daya yang professional tersebut yaitu melakukan atau mengikut sertakan karyawan dalam suatu pelatihan. Penelitian ini bertujuan untuk menganalisis pengaruh pelatihan kerja terhadap kinerja karyawan pada PT. Penerbit Erlangga Cabang Samarinda.Pengolahan data dalam penelitian ini menggunakan software SPSS 17 for windows, sedangkan untuk pengujian menggunakan kuesioner di uji validitas dan uji reliabilitas sebelum penelitian. Uji asumsi klasik yang digunakan adalah uji normalitas. Uji hipotesis yang digunakan adalah regresi linear sederhana. Setelah melakukan analisis terhadap data yang diperoleh dari responden, maka peneliti dapat menyimpulkan bahwa pelatihan kerja berpengaruh pada kinerja karyawan pada PT. Penerbit Erlangga Cabang Samarinda.
\end{abstract}

Kata kunci: Pelatihan Kerja , Kinerja, Penerbit Erlangga.

\begin{abstract}
Employee performance is the results achieved and the achievements shown by employees that help the company achieve the goals it sets. One way that can be done to print these professional resources is to conduct or include employees in a training. This study aims to analyze the effect of job training on employee performance at PT. Publisher Erlangga Branch Samarinda. Data processing in this study used SPSS 17 for windows software, while for testing using a questionnaire in the validity test and reliability test before the study. The classic assumption test used is the normality test. The hypothesis test used is simple linear regression. After analyzing the data obtained from the respondents, the researcher concludes that job training has an effect on employee performance at PT. Erlangga Publisher, Samarinda Branch.
\end{abstract}

Keywords: Job Training, Performance, Publisher Erlangga

\section{PENDAhuluan}

Proses berjalannya sebuah perusahaan membutuhkan sistem yang mampu bekerja secara sinergi dan dinamis. Sistem ini melibatkan sumber daya manusia yang tepat atau sesuai dengan kemampuan yang dimiliki untuk mengelola sumber daya manusia.Sumber daya manusia merupakan salah satu faktor terpenting bagi keberhasilan suatu perusahaan mengingat sumber daya manusia merupakan penentu kegiatan perusahaan baik perencanaan, pengorganisasian, serta pengambilan keputusan. Sumber daya manusia yang dimaksud didalam sebuah perusahaan adalah karyawan. Salah satu cara yang dapat dilakukan untuk mencetak sumber daya yang professional tersebut yaitu melakukan atau mengikut sertakan karyawan dalam suatu pelatihan atau semacamnya. Pelatihan sering kita dengar dalam dunia kerja di perusahaan, organisasi, lembaga, 
atau bahkan dalam instansi pendidikan. Hal ini sering dilakukan sebagai upaya meningkatkan kinerja para tenaga kerja ataupun karyawan yang dianggap belum mampu untuk mengembangkan pekerjaannya.Untuk dapat meningkatkan keterampilan dan kemampuan kerja tersebut haruslah melalui berbagai pembinaan dalam bentuk berbagai perlatihan.Berdasarkan uraian pada latar belakang yang telah dikemukakan di atas, maka perumusan masalah dalam penulisan laporan ini adalah "Apakah Pelatihan Kerja Berpengaruh Signifikan Terhadap Kinerja Karyawan Pada PT. Penerbit Erlangga cabang Samarinda?'Pengertian Manajemen Sumber Daya Manusia (MSDM). Manajemen sumber daya manusia adalah suatu ilmu atau cara bagaimana mengatur hubungan dan peranan sumber daya (tenaga kerja) yang dimiliki oleh individu secara efisien dan efektif serta dapat digunakan secara maksimal sehingga tercapai tujuan (goal) bersama perusahaan, karyawan dan masyarakat menjadi maksimal. Menurut (Ghozali 2000) dalam buku (Mamik, 2016) manajemen Sumber Daya Manusia terdiri dari dua kata yaitu : manajemen dan sumber daya manusia. Manajemen berasal dari kata to manage yang berarti mengelola, menata, mengurus, mengatur atau mengendalikannya.Menurut (Hamalik, 2007) pelatihan adalah suatu proses yang meliputi serangkaian tindak (upaya) yang dilaksanakan dengan sengaja dalam bentuk pemberian bantuan kepada tenaga kerja yang dilakukan oleh tenaga professional kepelatihan dalam satuan waktu, yang bertujuan untuk meningkatkan kemampuan kerja peserta dalam bidang pekerjaan tertentu guna meningkatkan efektivitas dan produktivitas dalam suatu organisasi.

Menurut (Mangkuprawira 2009) dalam buku (Sudaryo, Aribowo, \& Sofiati, 2018) performance atau kinerja adalah hasil keja yang dapat dicapai oleh seseorang atau kelompok orang dalam suatu organisasi sesuai dengan wewenang dan tanggung jawabnya masing-masing dalam upaya pencapaian tujuan organisasi. Kinerja karyawan adalah hasil yang dicapai dan prestasi yang ditunjukkan oleh karyawan yang membantu perusahaan untuk mewujudkan tujuan yang ditetapkannya.

Berdasarkan landasan teori dan hasil penelitian terdahulu, maka kerangka pikir dalam penelitian ini adalah sebagai berikut:

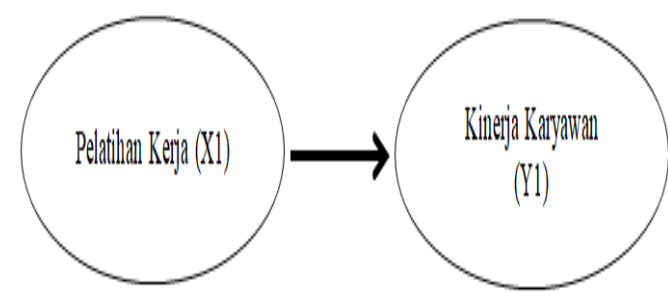

Gambar 1 Krangka Pemikiran

\section{Pengembangan Hipotesis}

Hipotesis merupakan dugaan sementara dari permasalahan yang harus dibuktikan kebenarannya melalui data yang ada.Hal tersebut dapat diketahui apabila data yang dikumpulkan telah teruji kebenarannya.Diperlukan hipotesis dimaksudkan untuk melihat seberapa jauh perkembangan variabel yang diuji dalam penulisan tugas akhir ini.

Berdasarkan dari uraian pada dasar teori yang penulis kemukakan dan data yang penulis peroleh, maka hipotesis dalam penulisan tugas akhir ini adalah:

H0: $\quad$ Pelatihan Kerja tidak berpengaruh signifikan terhadap Kinerja Karyawan Pada PT. Penerbit Erlangga Cabang Samarinda.

Ha : Pelatihan Kerja berpengaruh signifikan terhadap Kinerja Karyawan Pada PT. Penerbit Erlangga Cabang Samarinda

Adapun tujuan dari penelitian adalah "Untuk mengetahui pengaruh pelatihan kerja terhadap kinerja karyawan pada PT. Penerbit Erlangga cabang Samarinda." 


\section{METODOLOGI}

Penelitian ini dilakukan di PT. Penerbit Erlangga Cabang Samarinda Jl. Bung Tomo, No. 134, Kel.Sei Keledang Kec. Samarinda Seberang, Kota Samarinda, Kalimantan Timur 75132 dengan tujuan untuk mengetahui pelatihan kerja terhadap kinerja karyawan PT. Penerbit Erlangga.

Dalam penelitian ini populasinya adalah karyawan PT. Penerbit Erlangga yang berjumlah 25 orang.Penentuan sampel dalam penelitian ini menggunakan metode sampling jenuh yaitu mengambil seluruh anggota populasi menjadi responden yaitu sebanyak 25 orang sebagai sampel responden.

Proses pengumpulan data yang diperlukan dalam pembahasan ini melalui tiga tahap penelitian, yaitu:

a. Studi Pustaka: Studi pustaka digunakan dengan cara mempelajari, mengkaji serta menelah literatur-literatur berupa buku, jurnal, dan hasil penelitian yang terdapat hubungan dengan objek penelitian.

b. Observasi; Observasi merupakan suatu teknik dengan cara melakukan pengamatan langsung pada obyek yang diteliti sehingga diperoleh gambaran yang jelas mengenai masalah yang dihadapi.

c. Kuisioner

Kuisioner adalah pengumpulan data dengan cara menyebarkan daftar pernyataan kepada responden yang dijadikan sebagai sampel penelitian.

\section{HASIL DAN PEMBAHASAN}

Penjelasan masing-masing variabel Pengamatan tersebut adalah sebagai berikut:

Service Quality adalah persepsi pelanggan berkaitan dengan upaya perusahaan dalam melayani, memenuhi kebutuhan dan keinginan, serta ketepatan penyampaian untuk mengimbangi harapan pelanggan. Untuk mengukur Service Quality digunakan 5 indikator diadopsi yakni :

a. Bukti langsung (tangibles), yaitu hal yang berkaitan dengan penampilan fasilitas fisik, seperti design interior, kebersihan, kerapian dan kenyamanan ruangan tunggu, kelengkapan peralatan dan penampilan karyawan. Dengan item pernyataan sebagai berikut : Karyawan Swiss-Belhotel Borneo Samarinda berpenampilan rapi saat bekerja (X1.1)

b. Kehandalan (reliability) merupakan kemampuan memberikan pelayanan yang dijanjikan dengan segera, akurat dan memuaskan. Dengan item pernyataan sebagai berikut : Karyawan Swiss-Belhotel Borneo Samarinda cepat dan tepat dalam melayani pelanggan (X1.2).

c. Daya Tanggap (responsiveness) berarti respon atau kesigapan karyawan dalam membantu dan memberikan pelayanan yang cepat, dan yang meliputi kesigapan karyawan dalam melayani pelanggan, kecepatan karyawan menangani transaksi, dan penanganan. Dengan item pernyataan sebagai berikut : Karyawan Swiss-Belhotel Borneo Samarinda menanggapi setiap permintaan pelanggan denga cepat (X1.3)

d. Jaminan (assurance) mencakup pengetahuan, kesopanan, dan kemampuan, dari para staf untuk dapat menimbulkan kepercayaan dan keyakinan dari pelanggan. Dengan item pernyataan sebagai berikut : Karyawan Swiss-Belhotel Borneo Samarinda mampu memberikan keamanan pada saat bertransaksi (X1.4).

e. Empati (emphaty) merupakan suatu sikap yang dimiliki oleh para staf untuk dapat memberikan kepedulian atau dapat memberikan perhatian kepada pelanggan. Dengan item pernyataan sebagai berikut : Karyawan Swiss-Belhotel Borneo Samarinda memahami kebutuhan pelanggan (X1.5) 


\section{Uji Validitas}

Berdasarkan hasil uji validitas pada tabel dibawah seluruh item atau pernyataan pada kuesioner dinyatakan nilai $r$ hitung $>r$ tabel $(n=114)$ yaitu:

Tabel 1. Hasil Uji Validitas Variabel Harapan

\begin{tabular}{|c|c|c|c|c|}
\hline Variabel & Indikator & R hitung & R tabel & Keterangan \\
\hline \multirow{5}{*}{ X1.1 } & 0.642 & 0.1840 & Valid \\
\cline { 2 - 5 } & $\mathrm{X} 1.2$ & 0.657 & 0.1840 & Valid \\
\cline { 2 - 5 } & $\mathrm{X} 1.3$ & 0.527 & 0.1840 & Valid \\
\cline { 2 - 5 } & $\mathrm{X} 2.1$ & 0.603 & 0.1840 & Valid \\
\cline { 2 - 5 } & $\mathrm{X} 2.2$ & 0.614 & 0.1840 & Valid \\
\cline { 2 - 5 } & $\mathrm{X} 2.3$ & 0.710 & 0.1840 & Valid \\
\cline { 2 - 5 } & $\mathrm{X} 2.4$ & 0.662 & 0.1840 & Valid \\
\cline { 2 - 5 } & $\mathrm{X} 2.5$ & 0.578 & 0.1840 & Valid \\
\cline { 2 - 5 } & $\mathrm{X} 2.6$ & 0.675 & 0.1840 & Valid \\
\cline { 2 - 5 } & $\mathrm{X} 3.1$ & 0.699 & 0.1840 & Valid \\
\cline { 2 - 5 } & $\mathrm{X} 3.2$ & 0.670 & 0.1840 & Valid \\
\cline { 2 - 5 } & $\mathrm{X} 3.3$ & 0.755 & 0.1840 & Valid \\
\cline { 2 - 5 } & $\mathrm{X} 4.1$ & 0.791 & 0.1840 & Valid \\
\cline { 2 - 5 } & $\mathrm{X} 4.2$ & 0.696 & 0.1840 & Valid \\
\cline { 2 - 5 } & $\mathrm{X} 4.3$ & 0.613 & 0.1840 & Valid \\
\cline { 2 - 5 } & $\mathrm{X} 4.4$ & 0.613 & 0.1840 & Valid \\
\cline { 2 - 5 } & $\mathrm{X} 5.1$ & 0.764 & 0.1840 & Valid \\
\cline { 2 - 5 } & $\mathrm{X} 5.2$ & 0.594 & 0.1840 & \\
\hline
\end{tabular}

Tabel 2 Hasil Uji Validitas Variabel Kinerja

\begin{tabular}{|c|c|c|c|c|}
\hline Variabel & Indikator & R hitung & R tabel & Keterangan \\
\hline \multirow{5}{*}{ KINERJA } & X1.1 & 0.680 & 0.1840 & Valid \\
\cline { 2 - 5 } & $\mathrm{X} 1.2$ & 0.619 & 0.1840 & Valid \\
\cline { 2 - 5 } & $\mathrm{X} 1.3$ & 0.509 & 0.1840 & Valid \\
\cline { 2 - 5 } & $\mathrm{X} 2.1$ & 0.659 & 0.1840 & Valid \\
\cline { 2 - 5 } & $\mathrm{X} 2.2$ & 0.628 & 0.1840 & Valid \\
\cline { 2 - 5 } & $\mathrm{X} 2.3$ & 0.737 & 0.1840 & Valid \\
\cline { 2 - 5 } & $\mathrm{X} 2.4$ & 0.808 & 0.1840 & Valid \\
\cline { 2 - 5 } & $\mathrm{X} 2.5$ & 0.657 & 0.1840 & Valid \\
\cline { 2 - 5 } & $\mathrm{X} 2.6$ & 0.660 & 0.1840 & Valid \\
\cline { 2 - 5 } & $\mathrm{X} 3.1$ & 0.759 & 0.1840 & Valid \\
\cline { 2 - 5 } & $\mathrm{X} 3.2$ & 0.802 & 0.1840 & Valid \\
\cline { 2 - 5 } & $\mathrm{X} 3.3$ & 0.816 & 0.1840 & Valid \\
\cline { 2 - 5 } & $\mathrm{X} 4.2$ & 0.740 & 0.1840 & Valid \\
\cline { 2 - 5 } & $\mathrm{X} 4.3$ & 0.792 & 0.1840 & Valid \\
\cline { 2 - 5 } & $\mathrm{X} 4.4$ & 0.689 & 0.1840 & Valid \\
\cline { 2 - 5 } & $\mathrm{X} 5.1$ & 0.761 & 0.1840 & Valid \\
\cline { 2 - 5 } & $\mathrm{X} 5.2$ & 0.734 & 0.1840 & \\
\cline { 2 - 5 } & $\mathrm{X} 5.3$ & 0.634 & 0.1840 & \\
\hline
\end{tabular}

Berdasarkan perbandingan tabel diatas dapat disimpulkan bahwa nilai $r$ hitung $>r$ tabel yang mana bisa di katakana bahwa semua butir soal variabel Harapan dan Kinerja sudah valid.

\section{Uji Reliabilitas}

Tabel 3. Hasil Uji Reliabilitas Variabel Harapan

\begin{tabular}{|c|c|c|c|c|}
\hline \multicolumn{2}{|c|}{ Variabel } & Alpha Chronbach's & Nilai Kritis & Keterangan \\
\hline \multirow{4}{*}{ Harapan } & X.1 & 0.788 & 0,60 & Realibel \\
\cline { 2 - 5 } & X.2 & 0.794 & 0,60 & Realibel \\
\cline { 2 - 5 } & X.3 & 0.864 & 0,60 & Realibel \\
\cline { 2 - 5 } & X.4 & 0.820 & 0,60 & Realibel \\
\cline { 2 - 5 } & X.5 & 0.826 & 0,60 & Realibel \\
\hline
\end{tabular}


Tabel 4 Hasil Uji Reliabilitas Variabel Kinerja

\begin{tabular}{|c|c|c|c|c|}
\hline \multicolumn{2}{|c|}{ Variabel } & Alpha Chronbach's & Nilai Kritis & Keterangan \\
\hline \multirow{4}{*}{ Kinerja } & X.1 & 0.783 & 0,60 & Realibel \\
\cline { 2 - 5 } & X.2 & 0.808 & 0,60 & Realibel \\
\cline { 2 - 5 } & X.3 & 0.873 & 0,60 & Realibel \\
\cline { 2 - 5 } & X.4 & 0.843 & 0,60 & Realibel \\
\cline { 2 - 5 } & X.5 & 0.842 & 0,60 & Realibel \\
\hline
\end{tabular}

Berdasarkan analisis yang di lakukan menggunakan rumus Alpha Chronbach's dengan bantuan software pengolah data yaitu spss di peroleh reliabilitas Harapan sebesar: (X.1 0.788, masuk dalam kategori cukup), (X.2 0.794, masuk dalam kategori cukup), (X.3 0.864, masuk dalam kategori tinggi), (X.4 0.820, masuk dalam kategori tinggi), (X.5 0.826, masuk dalam kategori tinggi). Sedangkan skala reliabilitas kinerja sebesar: (X.1 0,783, masuk dalam kategori cukup), (X.2 0.808, masuk dalam kategori tinggi), (X.3 0.873, masuk dalam kategori tinggi), (X.4 0.843, masuk dalam kategori tinggi), (X.5 0.842, masuk dalam kategori tinggi). Penentuan kategori skala reliabilitas didasarkan menurut tabel di bawah ini yang mana di kemukakan oleh Arikunto (2006:245)

Tabel 5 Indikator Besarnya Linier $\mathbf{R}$

\begin{tabular}{|c|c|}
\hline Besarnya linear $\mathbf{r}$ & Interpretasi \\
\hline $0,800-1,000$ & Tinggi \\
\hline $0,600-0,800$ & Cukup \\
\hline $0,400-0,600$ & Agak Rendah \\
\hline $0,200-0,400$ & Rendah \\
\hline $0,000-0,200$ & Sangat Rendah \\
\hline
\end{tabular}

Berdasarkan analisis yang di lakukan menggunakan rumus Alpha Chronbach's dengan bantuan software pengolah data yaitu spss di peroleh reliabilitas Harapan sebesar: (X.1 0.788, masuk dalam kategori cukup), (X.2 0.794, masuk dalam kategori cukup), (X.3 0.864, masuk dalam kategori tinggi), (X.4 0.820, masuk dalam kategori tinggi), (X.5 0.826, masuk dalam kategori tinggi). Sedangkan skala reliabilitas kinerja sebesar: (X.1 0,783, masuk dalam kategori cukup), (X.2 0.808, masuk dalam kategori tinggi), (X.3 0.873, masuk dalam kategori tinggi), (X.4 0.843, masuk dalam kategori tinggi), (X.5 0.842, masuk dalam kategori tinggi). Penentuan kategori skala reliabilitas didasarkan menurut tabel di bawah ini yang mana di kemukakan oleh Arikunto (2006:245).

\section{Analisis Diagram Kartesius Kesesuaian Harapan dan Kinerja Variabel Kualitas Pelayanan secara Bersama-sama}

Variabel kualitas pelayanan hotel dalam Pengamatan ini terdiri dari: Tangible, Reliability, Responsiveness, Assurance, dan Empathy. Kelima variabel tersebut dilakukan analisis nilai rerata masing-masing variabel untuk menentukan titik rata-rata dan persentase kesesuaian dalam diagram kartesius sebagaimana tabel berikur.

Tabel 6. Rerata Harapan dan Kinerja Kualitas Pelayanan Hotel

\begin{tabular}{|c|c|c|c|c|c|} 
Tangible & 1458 & 1436 & 12,60 & 12,79 & $101,5 \%$ \\
\hline Reliability & 2896 & 2800 & 24,56 & 25,40 & $103,4 \%$ \\
\hline Responsiveness & 1473 & 1407 & 12,34 & 12,92 & $104,7 \%$ \\
\hline Assurance & 1923 & 1871 & 16,41 & 16,87 & $102,8 \%$ \\
\hline Empathy & 1486 & 1444 & 12,67 & 13,04 & $102,9 \%$ \\
\hline Item & $y$ & $x$ & $(\overline{\bar{x}})$ & $(\overline{\bar{y}})$ & $(\bar{x})$ \\
\hline \multicolumn{7}{r|}{} & & 15,72 & 16,20 & $103,1 \%$ \\
\hline
\end{tabular}


Nilai rata-rata dari harapan $\overline{\boldsymbol{y}}$ dan kinerja $\overline{\boldsymbol{x}}$ sebagaimana di atas digunakan untuk menentukan posisi penempatan variabel Kualitas pelayanan pada kuadran diagram kartesius. Berikut adalah penempatan masing-masing variabel Kualitas tersebut.

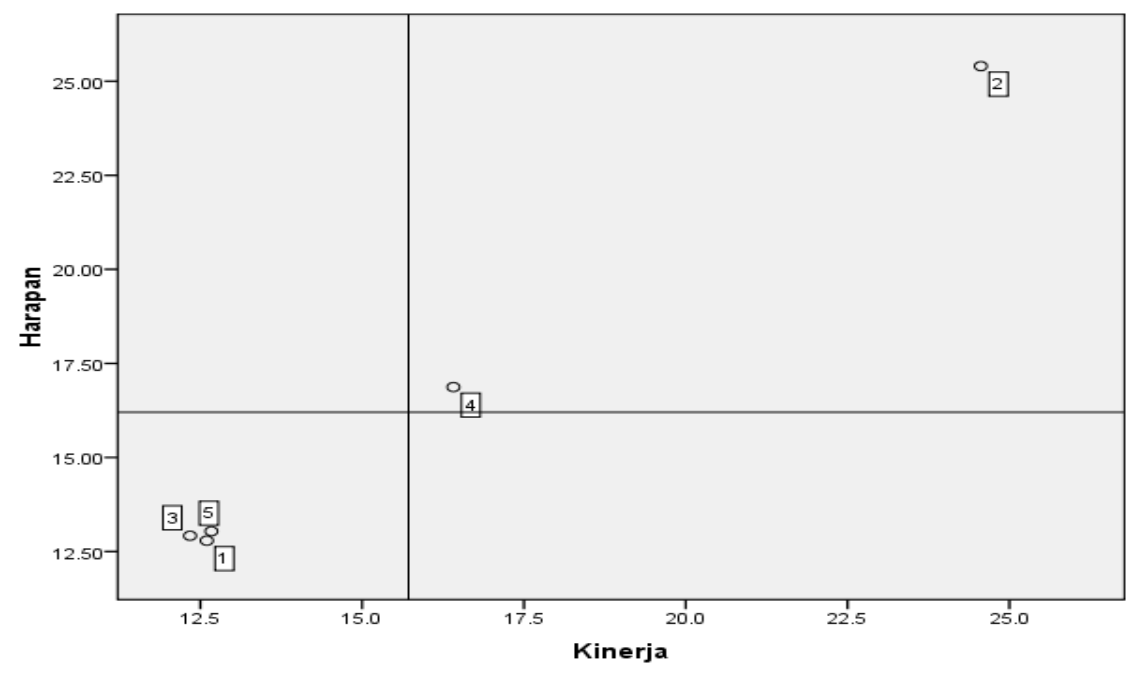

Gambar 1 Diagram Kartesius Variabel Kualitas Pelayanan

Hasil penempatan variabel Kualitas pada diagram kartesius sebagaimana gambar diatas lebih besar sebaran variabel terletak pada dua kuadran yang berbeda yaitu:

a. Kuadran B

Variabel yang terletak pada kuadran B adalah: variabel Reliability dan variabel Assurance. Jika dilihat dari kepentingan pelanggan pelaksanaan pelayanan yang menitikberatakn Reliability (fasilitas fisik yang sesuai, karyawan yang menepati janji tepat waktu, sikap karyawan yang simpatik, karyawan yang cepat saat diminta pelayanan, karyawan yang memberikan jasa sesuai waktu yang dijanjikan, dan karyawan yang cepat dan tepat) dan yang menitikberatkan pada assurance (kepercayaan pelanggan, aman saat bertransaksi dengan karyawan, karywan bersikap professional, dan dukungan dari instansi yang mendukung karyawan dalam tugasnya) saat ini berada pada tingkat pelaksanaan yang tinggi. Kemudian jika dilihat dari kinerja dan loyalitas pelanggan pada tingkat yang tinggi pula. Hal ini menuntuk manajemen hotel untuk dapat mempertahankan posisinya, karena bentuk pelayanan tersebutlah yang menarik minat pelanggan untuk menginap di hotel tersebut.

b. Kuadran C

Variabel yang terletak di kuadran ini adalah : Empathy, Responsiveness, dan Tangible. Jika dilihat dari harapan pelanggan bentuk pelayanan yang menitikberatkan pada empathy (karyawan menunjukkan sikap positif pada saat pelanggan dapat masalah, karyawan menunjukkan perbuatan positif kepapa pelanggan, dan karyawan menunjukkan ekspresi positif saat pelanggan tidak memperoleh kebutuhannya), menitikberatkan pada Responsiveness (karyawan selalu siap dalam memberi pelayanan, karyawan yang segera membantu saat diminta, dan karyawan langsung menanggapi permintaan pelanggan dengan cepat), menitikberatkan pada tangible (peralatan terbaru/mutakhit yang dimiliki hotel, fasilitas fisik, dan karyawan berpakaian dan berpenampilan rapi. Merupakan pelayanan yang saat ini kurang dianggap penting oleh pelanggan, tetapi jika dilihat dari kinerjanya, pelanggan merasa biasa-biasa saja. 


\section{Uji Paired T test}

Tabel 7 Paired Samples Statistics

\begin{tabular}{|c|c|c|c|c|}
\hline Variabel & Mean & $\mathbf{N}$ & Std. Deviation & Std. Error Mean \\
\hline Harapan & 4.264 & 19 & .0666 & .0153 \\
\hline Kinerja & 4.137 & 19 & .0793 & .0182 \\
\hline
\end{tabular}

Sumber : Hasil Kuesioner diolah, 2019

Dari tabel diatas adalah hasil statistic deskriptif dari kedua sampel yang diteliti yaitu Variabel harapan dan kinerja. Untuk harapan diperoleh rata-rata sebesar $(4,26)$. Sedangkan untuk rata-rata kinerja sebesar (4.13). Maka bisa dikatakan bahwa harapan pelanggn lebih besar dari kinerja.

Tabel 8 Paired Samples Correlations

\begin{tabular}{|c|c|c|c|}
\hline Variabel & N & Correlation & Sig. \\
\hline harapan \& kinerja & 19 & .655 & .002 \\
\hline
\end{tabular}

Dari tabel diatas menunjukkan hasil uji korelasi atau hubungan antata dua variabel. Berdasarkan data diatas diketahui nilai koefisien korelasi sebesar $(0,655)$ dengan nilai signifikan sebesar $(0,002)$. Karena nilai sig $<0,05$, maka dapat dikatakan bahwa ada hubungan antara variabel harapan dan kinerja.

Tabel 9 Paired Samples Test

\begin{tabular}{|c|c|c|c|c|c|c|c|c|}
\hline \multirow[b]{3}{*}{ Variabel } & \multicolumn{5}{|c|}{ Paired Differences } & \multirow[b]{3}{*}{$\mathrm{t}$} & \multirow[b]{3}{*}{$\mathrm{df}$} & \multirow[b]{3}{*}{ Sig. (2-tailed) } \\
\hline & \multirow[b]{2}{*}{ Mean } & \multirow[b]{2}{*}{ Std. Deviation } & \multirow{2}{*}{$\begin{array}{l}\text { Std. Error } \\
\text { Mean }\end{array}$} & \multicolumn{2}{|c|}{$\begin{array}{l}95 \% \text { Confidence } \\
\text { Interval of the } \\
\text { Difference }\end{array}$} & & & \\
\hline & & & & Lower & Upper & & & \\
\hline harapan - kinerja & .1274 & .0617 & .0142 & .0976 & .1571 & 8.995 & 18 & .000 \\
\hline
\end{tabular}

Sumber : Hasil Kuesioner diolah, 2019

Dari tabel diatas diketahui nilai sig. (2-tailed) adalah sebesar $(0.000)<(0,05)$ maka $\mathrm{H}_{\mathrm{o}}$ ditolak dan $\mathrm{H}_{\mathrm{a}}$ diterima. sehingga dapat diketahui bahwa adanya perbedaan yang signifikan antara harapan dan kinerja kualitas pelayanan.

\section{KESIMPULAN}

Berdasarkan hasil Pengamatan seperti yang telah diuraikan pada bab sebelumnya dapat ditarik kesimpulan yaitu, berdasarkan uji hipotesis diketahui bahwa adanya perbedaan yang signifikan antara harapan dan kinerja kualitas pelayanan hotel bisa dilihat dari nilai sig. (2-tailed) $<0,05$ sehingga $\mathrm{H}_{\mathrm{o}}$ ditolak $\mathrm{H}_{\mathrm{a}}$ diterima. Berdasarkan analisis diagram kartesius ditemukan dua variabel di dalam kuadran B dan tiga di dalam kuadran $\mathrm{C}$. 


\section{DAFTAR PUSTAKA}

Hasibuan, M. (2006). Manajemen Dasar, Pengertian, dan Masalah. Jakarta: Bumi Aksara.

Kotler, P. (2009). Manajemen Pemasaran (13th ed.). Jakarta: Erlangga.

Lupioyadi, R. (2001). Manajeman Pemasaran Jasa. Salemba Pusat.

Tjiptono, F. (2008). Pemasaran Strategik (1st ed.). Yogyakarta: Andi Offset.

Widyaningtyas, R. (2010). Faktor-faktor yang mempengaruhi Loyalitas Dan Dampaknya Pada Kepercayaan Nasabah Dalam Menggunakan Jasa kereta Api Harina. Skripsi Fakultas Ekonomi Universitas Diponegoro. 